\title{
Kinetic and galvanostatic studies of a polymer electrolyte for lithium-ion batteries
}

\author{
Agnieszka Swiderska-Mocek $^{1} \cdot$ Pawel Jakobczyk $^{1}$ • Andrzej Lewandowski ${ }^{1}$
}

Received: 6 March 2017 /Revised: 10 April 2017 / Accepted: 16 April 2017 /Published online: 29 April 2017

(C) The Author(s) 2017. This article is an open access publication

\begin{abstract}
Quaternary polymer electrolyte (PE) based on poly(acrylonitrile) (PAN), 1-ethyl-3-methylimidazolium tetrafluoroborate ionic liquid $\left(\mathrm{EMImBF}_{4}\right)$, sulfolane (TMS) and lithium hexafluorophosphate salt $\left(\mathrm{LiPF}_{6}\right)\left(\mathrm{PAN}^{-\mathrm{EMImBF}_{4}-}\right.$ sulfolane- $\mathrm{LIPF}_{6}$ ) was prepared by the casting technique. Obtained PE films of ca. $0.2-0.3 \mathrm{~mm}$ in thickness showed good mechanical properties. They were examined using scanning electron microscopy (SEM), thermogravimetry (TGA, DSC), the flammability test, electrochemical impedance spectroscopy (EIS) and galvanostatic charging/discharging. SEM images revealed a structure consisting of a polymer network (PAN) and space probably occupied by the liquid phase $\left(\mathrm{LiPF}_{6}+\mathrm{EMImBF}_{4}+\right.$ sulfolane). The polymer electrolyte in contact with an outer flame source did not ignite; it rather underwent decomposition without the formation of flammable products. Room temperature specific conductivity was ca. $2.5 \mathrm{mS} \mathrm{cm}^{-1}$. The activation energy of the conding process was ca. $9.0 \mathrm{~kJ} \mathrm{~mol}^{-1}$. Compatibility of the polymer electrolyte with metallic lithium and graphite anodes was tested applying the galvanostatic method. Charge transfer resistance for the $\mathrm{C}_{6} \mathrm{Li} \rightarrow \mathrm{Li}^{+}+\mathrm{e}^{-}$anode processes, estimated from EIS curve, was ca. $48 \Omega$. The graphite anode capacity stabilizes at ca. $350 \mathrm{mAh} \mathrm{g}^{-1}$ after the 30th cycle $\left(20 \mathrm{~mA} \mathrm{~g}^{-1}\right)$.
\end{abstract}

Keywords Polymer electrolyte · Ionic liquid · Sulfolane · Graphite anode $\cdot$ Li-ion battery

Agnieszka Swiderska-Mocek

agnieszka.swiderska-mocek@put.poznan.pl

1 Faculty of Chemical Technology, Poznan University of Technology, 60965 Poznan, Poland

\section{Introduction}

Lithium-ion batteries, because of their high gravimetric and volumetric energies, are widely used in portable electronic devices (laptops, tablet PCs, smart-phones). They commonly contain liquid electrolytes based on lithium salts and organic volatile solvents [1-3]. Because of the safety hazard associated with the flammable nature of organic liquid electrolytes, widespread use of LIBs in hybrid electric vehicles (HEVs) and electric-load levelling systems combined with renewable energy plants (REPs) is difficult. Using ionic liquid (ILs) as components of the electrolyte (solvent for the lithium salt or an additive to the electrolyte) increases battery safety level. Such compounds, in addition to being non-volatile and nonflammable, also exhibit good conductivity, high chemical and thermal stability [4-7]. The use of a polymer electrolyte (PE) eliminates the danger of leakage of liquid electrolyte. PEs have been extensively studied and described in the literature [8-14]. In turn, the inclusion of an ionic liquid into the polymer electrolyte provides additional benefits (apart from safety). Namely, polymer electrolytes based on a polymer matrix and an ionic liquid represent an attractive solution, since they combine mechanical and chemical stability of the polymer component with the intrinsic non-flammable nature as well as high thermal stability. Various polymers such as PEO [15-24], homo- and co-polymers of poly(vinylidene fluoride) (PVdF) [25-33] and poly(acrylonitrile) [34-37] have been used to prepare polymer electrolytes containing an ionic liquid and have been studied over the last few years. Another interesting is connected with poly(ionic liquids) (PILs), because of their acceptable ionic conductivity and good mechanical strength [38-40]. Different plasticizers are added in order to lower the glass transition temperature of the host polymer and therefore improve ionic conductivity, as well as increase flexibility of the polymer electrolyte. Various types of additives 
may be used as polymer electrolyte plasticizers, e.g. ionic liquids, monomer/oligomer units of the polymer and organic solvents (e.g. sulfolane) [14]. The general aim of the present study was to prepare a new, quaternary polymer electrolyte based on poly(acrylonitrile) polymer (PAN), lithium hexafluorophosphate salt $\left(\mathrm{LiPF}_{6}\right)$, sulfolane (TMS) and 1ethyl-3-methylimidazolium tetrafluoroborate ionic liquid $\left(\mathrm{EMImBF}_{4}\right)$. The PAN-EMImBF 4 -TMS-LIPF 6 polymer electrolyte system was characterized in terms of its ionic conductivity and thermal stability. Electrochemical properties of the polymer electrolyte were tested using Li metal and graphite $\left(\mathrm{C}_{6} \mathrm{Li}\right)$ electrodes.

\section{Experimental}

\section{Materials}

Graphite (G, SL-20, BET surface area $6.0 \mathrm{~m}^{2} \mathrm{~g}^{-1}$, Superior Graphite, USA), carbon black (CB, Fluka), poly(acrylonitrile) (PAN, $M_{\mathrm{W}}=150,000$, Aldrich), poly(vinylidene fluoride) $\left(\mathrm{PVdF}, M_{\mathrm{W}}=180,000\right.$ Fluka), vinylene carbonate $(\mathrm{VC}$, Aldrich), sulfolane (TMS, Fluka), $N$-methyl-2-pyrrolidinone (NMP, Fluka), dimethylformamide (DMF, Aldrich), lithium hexafluorophosphate ( $\mathrm{LiPF}_{6}$, Aldrich) and 1-ethyl-3methylimidazolium tetrafluoroborate $\left(\mathrm{EMImBF}_{4}\right.$, Aldrich) were used as received. PE was prepared by the casting technique. First, the polymer (PAN) was swollen in DMF at $50^{\circ} \mathrm{C}$. Then, the previously prepared solution of lithium salt in a mixture of 1-ethyl-3-methylimidazolium tetrafluoroborate and sulfolane (EMImBF 4 : TMS (70: 30)) was added to the PAN dimethylformamide solution. The resulting viscous solution was cast onto a glass plate and was subjected to the slow drying process (in the stream of dry argon, first at room temperature, then at $60{ }^{\circ} \mathrm{C}$ and finally at reduced pressure). It usually took 4-5 days; the composition of the system was monitored by weight (with an accuracy of $10^{-4} \mathrm{~g}$ ). If the weight of non-volatile components was achieved, this suggested that DMF was completely removed. Finally, free-standing, optically homogeneous and transparent membranes were obtained, with composition of ca. $12 \mathrm{wt} \%$ of the polymer (PAN), ca. $6 \mathrm{wt} \%$ of lithium salt $\left(\mathrm{LiPF}_{6}\right)$, ca. $57 \mathrm{wt} \%$ of ionic liquid $\left(\mathrm{EMImBF}_{4}\right)$ and ca. 24 wt $\%$ of sulfolane as a plasticizer. PEs were soaked with two drops (ca. $2.5 \mathrm{mg}$ ) of vinylene carbonate (VC, 5-7 wt \%) before cell assembly. After the addition of vinylene carbonate to the polymer electrolyte, the membrane was left for $2 \mathrm{~h}$. Tested anodes were prepared on a copper foil (Hohsen, Japan) from a slurry of graphite $(\mathrm{G})$, carbon black (CB) and PVdF in NMP. The ratio of components was $\mathrm{G} / \mathrm{CB} / \mathrm{PVdF}=85: 5: 10$ (by weight). After vacuum evaporation of the solvent (NMP) at $120{ }^{\circ} \mathrm{C}$, electrodes typically contained 3.5-
$4.2 \mathrm{mg}$ of graphite. A round-shaped lithium electrode (Aldrich, $0.75 \mathrm{~mm}$ thick) was used as the counter and reference electrode.
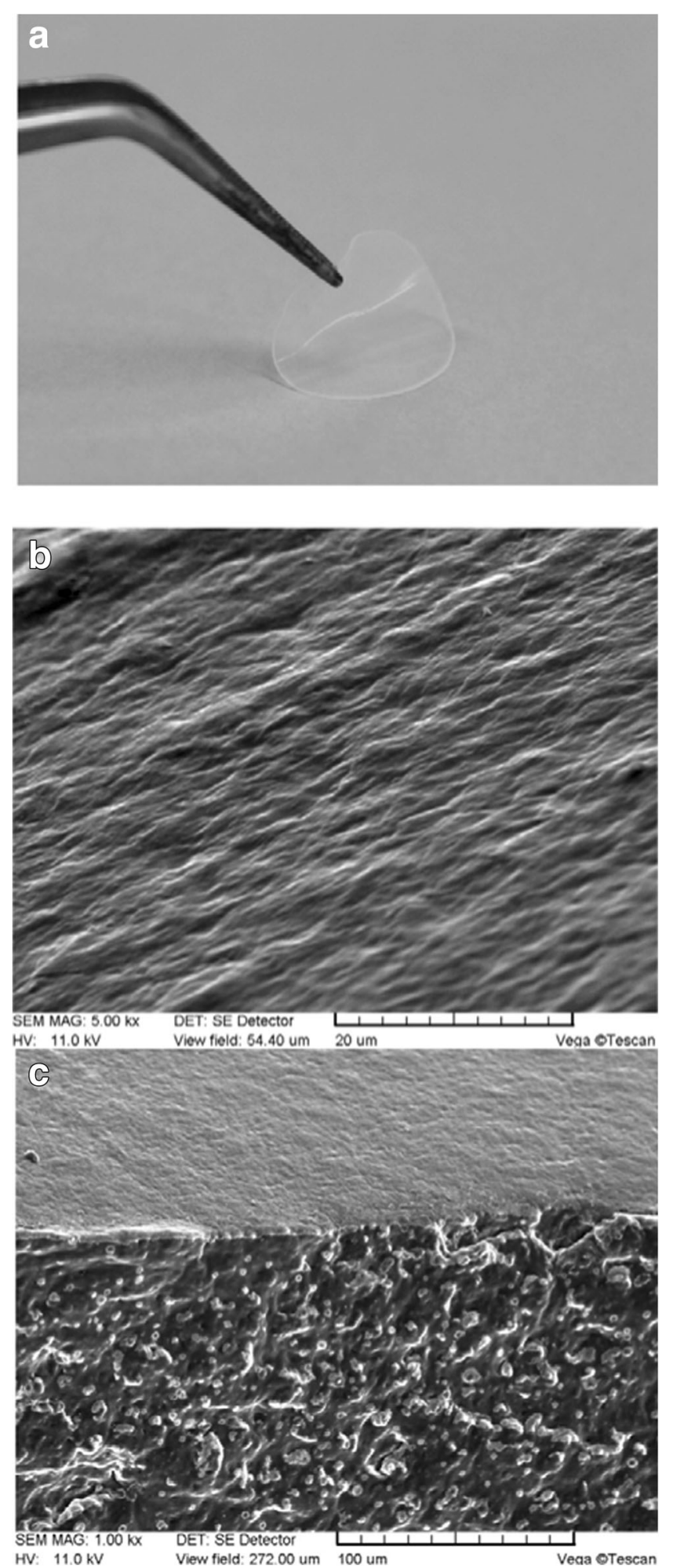

Fig. 1 a Picture of polymer electrolyte (PE), b SEM image of PE surface, c SEM image of PE cross section. PE composition: 12 wt $\%$ PAN, 6 wt $\%$ $\mathrm{LiPF}_{6}, 57 \mathrm{wt} \% \mathrm{EMImBF}_{4}$ and $24 \mathrm{wt} \%$ TMS 
Fig. 2 Flame test of glass fibre separator soaked with 'classical' liquid electrolyte $1 \mathrm{M} \mathrm{LiPF}_{6}$ in $\mathrm{EC}+\mathrm{DMC}$
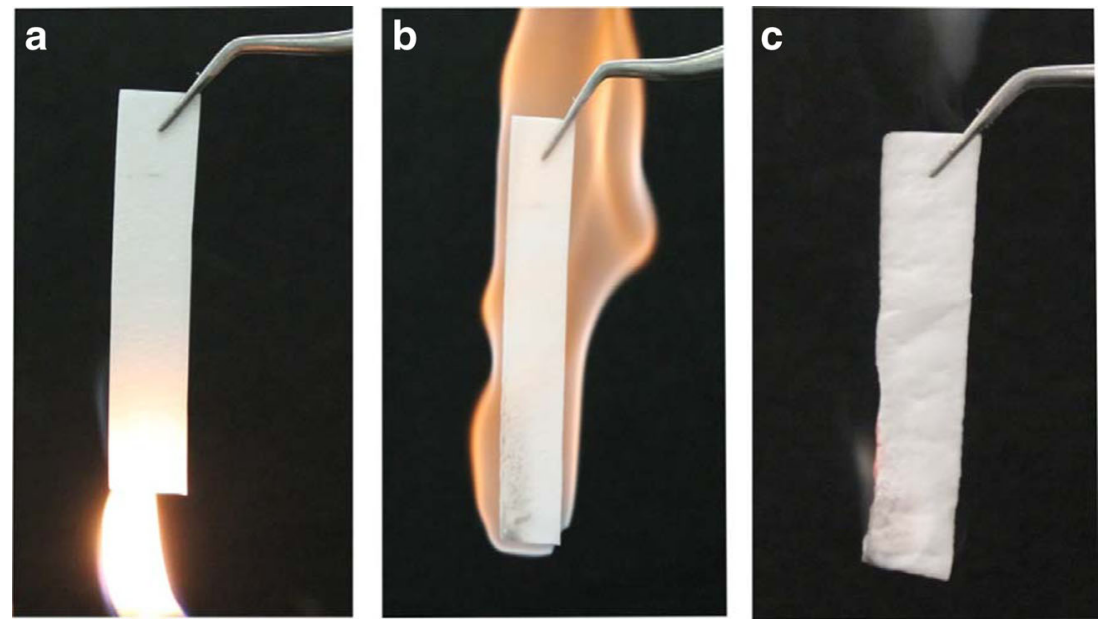

\section{Procedure and measurements}

Conductivity of PEs, sandwiched between two gold blocking electrodes, was measured in an adopted Swagelok $₫$ connecting tube placed in an air thermostat. Impedance spectra were recorded between $1 \mathrm{~Hz}$ and $10 \mathrm{kHz}$ at the amplitude of $10 \mathrm{mV}$. Electrochemical impedance spectroscopy (EIS) was performed with the use of the G750 Potentiostat/Galvanostat Measurements System (Gamry, USA) at different temperatures. The decomposition temperature of the polymer electrolyte was investigated by thermal gravimetry TG-DTA (Setsys 1200 analyser Setaram Instrumentation, France), recording weight loss from 20 up to $500{ }^{\circ} \mathrm{C}$ at $2{ }^{\circ} \mathrm{C} \mathrm{min}^{-1}$. Flame tests were based on direct observation of electrolyte ignition and burning. Flame test of the 'classical' liquid electrolyte $\left(1 \mathrm{M} \mathrm{LiPF}_{6}\right.$ solution in $\mathrm{EC}+\mathrm{DMC}$ ) was performed by soaking a glass fibre separator (GF/A, Whatman) with the electrolyte. Then, the separator with the liquid electrolyte or a strip of polymer electrolyte was exposed to a gas burner and flame propagation was observed. Scanning electron microscopy (SEM) of polymer electrolytes and electrodes was performed with the Tescan Vega 5153 apparatus. $\mathrm{Li} / \mathrm{PE} / \mathrm{LI}$ and $\mathrm{LiC}_{6} / \mathrm{PE} / \mathrm{Li}$ cells were prepared by sandwiching the polymer electrolyte films between two lithium metal foils or lithium foil and the graphite anode in an adapted $0.5^{\prime \prime}$ Swagelok ${ }^{\circledR}$ connecting tube. Cells were assembled in a dry argon atmosphere in a glove box. The electrochemical characteristic of the $\mathrm{LiC}_{6} / \mathrm{PE} / \mathrm{Li}$ cells was investigated using electrochemical impedance spectroscopy (EIS) and galvanostatic charging/discharging tests. Galvanostatic measurements were taken with the use of the ATLAS 0461 MBI multichannel electrochemical system (Atlas-Solich, Poland). Constant current charging/discharging cycles for the $\mathrm{LiC}_{6} / \mathrm{PE} / \mathrm{Li}$ cell were conducted between 2.5 and $0.005 \mathrm{~V}$ versus the lithium reference.

\section{Results and discussion}

\section{Polymer electrolyte morphology}

$\mathrm{PAN}+\mathrm{LIPF}_{6}+\mathrm{EMImBF}_{4}+\mathrm{TMS}$ polymer electrolyte was obtained as a transparent, flexible membrane of ca. $0.2-$ $0.3 \mathrm{~mm}$ in thickness (Fig. 1a). A SEM image of PE cross
Fig. 3 Flame test of polymer electrolyte (composition: $12 \mathrm{wt} \%$ PAN, $6 \mathrm{wt} \% \mathrm{LiPF}_{6}, 57 \mathrm{wt} \%$ $\mathrm{EMImBF}_{4}$ and $24 \mathrm{wt} \% \mathrm{TMS}$ )
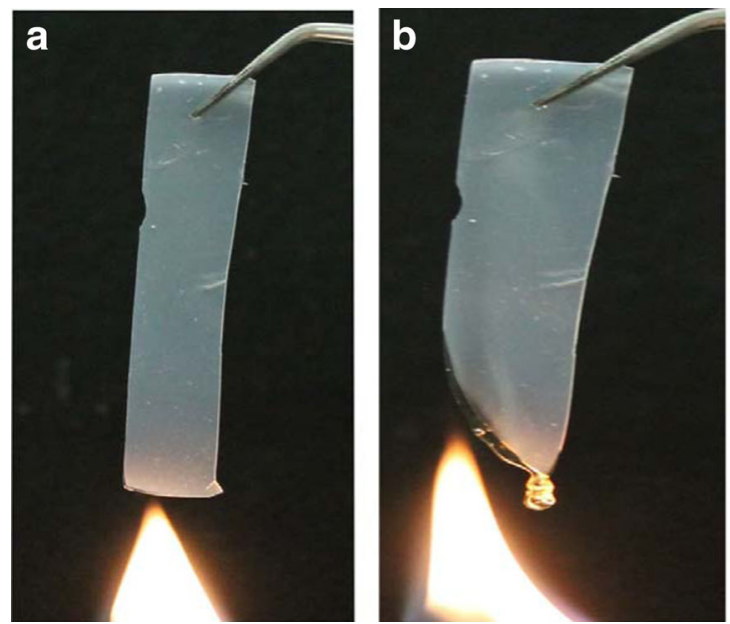
section taken at $1000 \times$ magnification (Fig. 1b) reveals a structure consisting of the polymer network (PAN) and space probably occupied by the liquid phase $\left(\mathrm{LiPF}_{6}+\mathrm{EMImBF}_{4}+\right.$ TMS). Surface of the PE was not perfectly even, as evidenced by a SEM image taken at a $5000 \times$ magnification (Fig. 1c). The surface seems to be covered, at least partially, by a solid (PAN or PAN and $\mathrm{LIPF}_{6}$ ) arrayed in one direction.

\section{Thermal stability and flammability}

One of the main drawbacks of 'classical' electrolytes based on cyclic carbonates is their relatively high vapour pressure and flammability. Figure 2 shows a flame test of the glass fibre separator soaked with $1 \mathrm{M} \mathrm{LiPF}_{6}$ solution in the mixture of EC + DMC (1:1). It may be seen that after ignition of the system with an outer flame source (Fig. 2a), the electrolyte burns away (Fig. 2b) completely (Fig. 2c). In contrast, the PE in contact with an outer flame source did not burn with visible flame; it rather undergoes softening (Fig. 3b, c). This indicates that decomposition of the PE does not result in the formation of flammable products. Figure 4 shows TG-DTA curves of the polymer electrolyte. Noticeable decomposition starts at around $200{ }^{\circ} \mathrm{C}$ and more noticeable at $350{ }^{\circ} \mathrm{C}$. For comparison, DSC of a liquid 'classic' electrolyte (1 M $\mathrm{LiPF}_{6}$ in EC + DMC) is shown in Fig. 5. Three phase transition peaks can be seen at the following temperatures: first ca. $80{ }^{\circ} \mathrm{C}$ (DMC boiling point $90{ }^{\circ} \mathrm{C}$ ), second $190{ }^{\circ} \mathrm{C}\left(\mathrm{LiPF}_{6}\right.$ melting point $\left.200{ }^{\circ} \mathrm{C}\right)$ and $230-280{ }^{\circ} \mathrm{C}$ with the maximum at $270{ }^{\circ} \mathrm{C}$ (EC boiling point $243{ }^{\circ} \mathrm{C}$ ). On the other hand, PE shows two peaks on the heat flow curve, one at ca. $280{ }^{\circ} \mathrm{C}$ and the second at ca. $430{ }^{\circ} \mathrm{C}$. The pure $\mathrm{LiPF}_{6}$ salt decomposition path is a dissociation producing gaseous $\mathrm{PF}_{5}$ [41]. This suggests that at increased

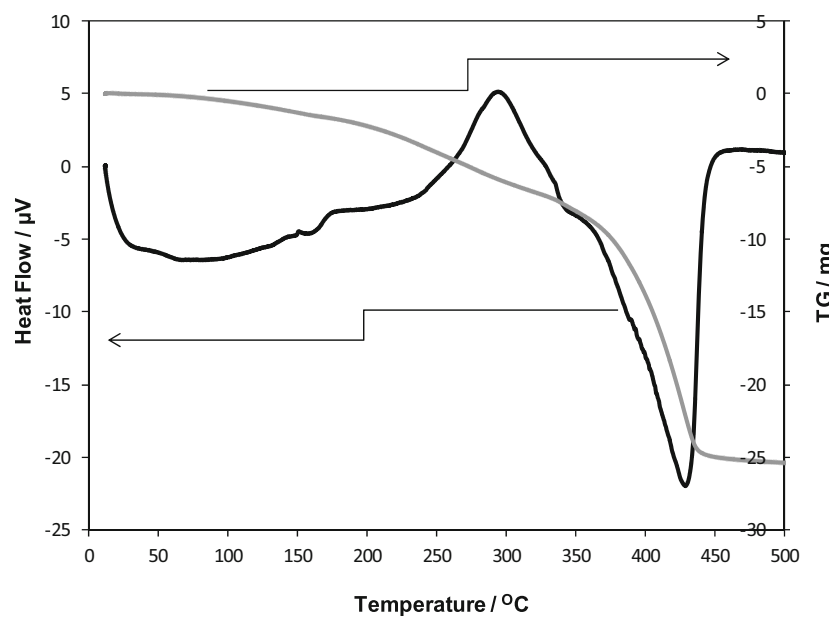

Fig. 4 Thermo-gravimetric analysis (TG-DTA), under flowing nitrogen in the temperature range between 20 and $500{ }^{\circ} \mathrm{C}$, of polymer electrolyte (composition: $12 \mathrm{wt} \%$ PAN, $6 \mathrm{wt} \% \mathrm{LiPF}_{6}, 57 \mathrm{wt} \% \mathrm{EMImBF}_{4}$ and $24 \mathrm{wt} \% \mathrm{TMS}$ )

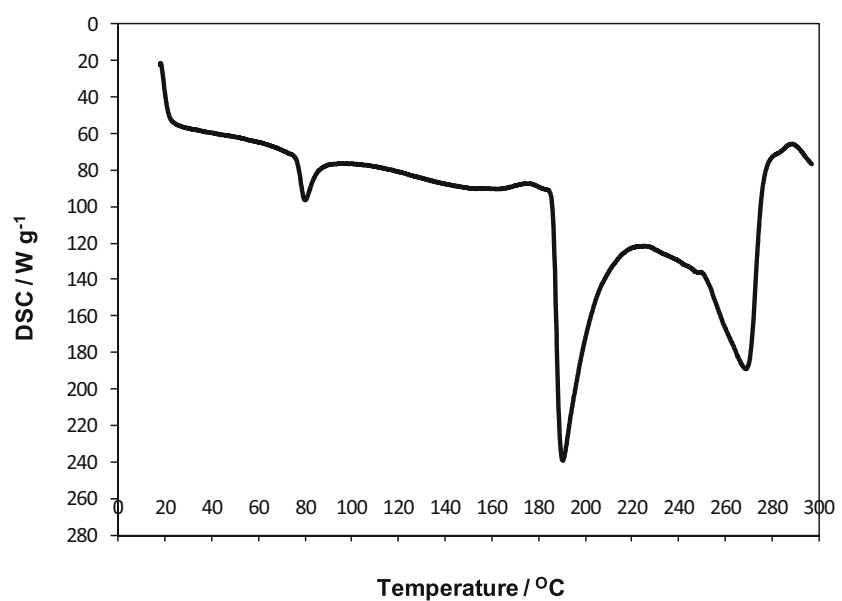

Fig. 5 Differential scanning calorimetry analysis (DSC), under flowing nitrogen in the temperature range between 20 and $300{ }^{\circ} \mathrm{C}$, of liquid electrolyte $1 \mathrm{M} \mathrm{LiPF}_{6}$ in $\mathrm{EC}+\mathrm{DMC}$
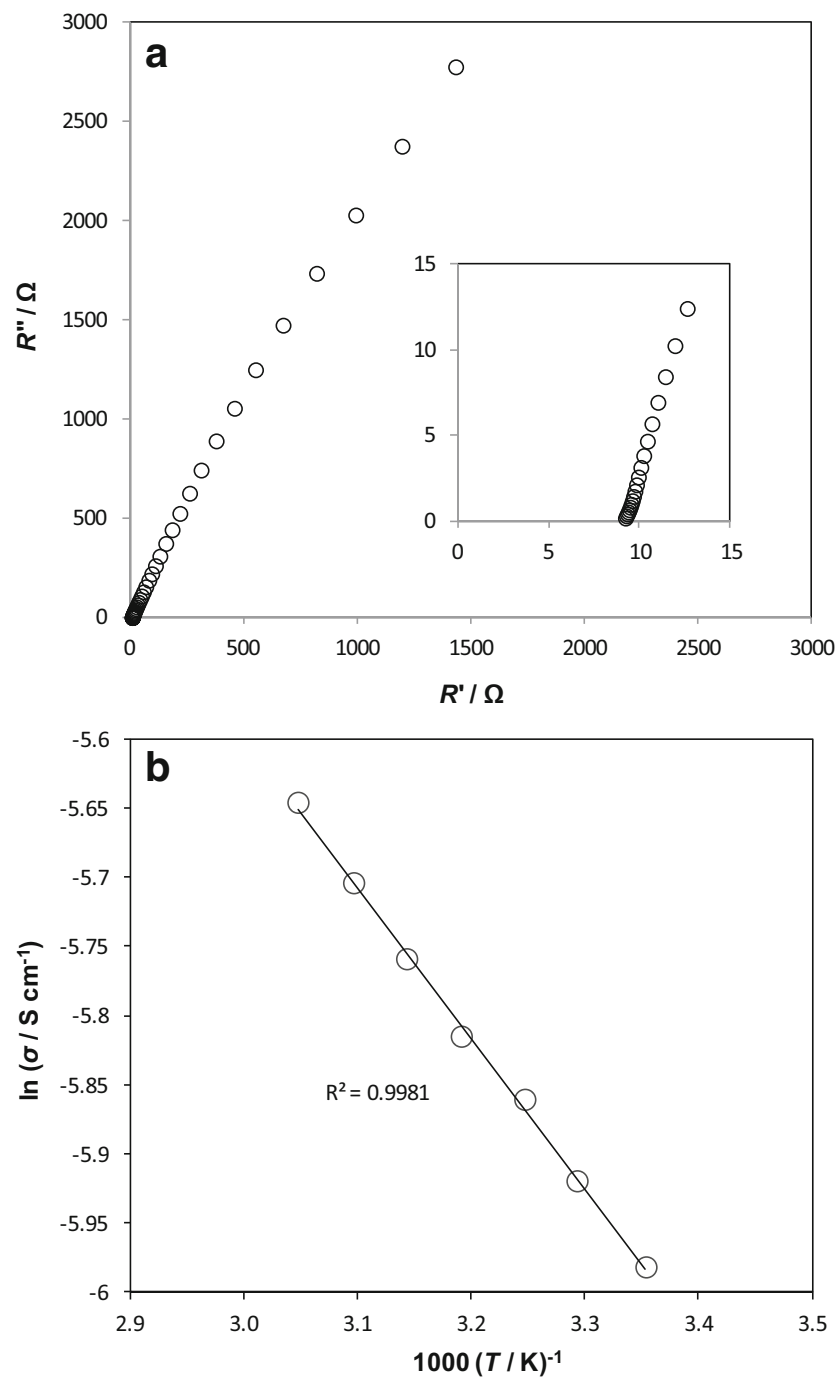

Fig. 6 Impedance spectroscopy of the $\mathrm{Au}|\mathrm{PE}+\mathrm{VC}| \mathrm{Au}$ cell at $25^{\circ} \mathrm{C}(\mathbf{a})$ and Arrhenius plot for the conduction process (b) 
Fig. 7 Impedance spectroscopy of the $\mathrm{Li}|\mathrm{PE}| \mathrm{Li}(\mathbf{a}), \mathrm{Li}|\mathrm{PE}+\mathrm{VC}| \mathrm{Li}$ (b) cells before and after galvanostatic charging/ discharging with current of $1 \mathrm{~mA}$, together with the equivalent circuit (c) used for impedance spectra deconvolution
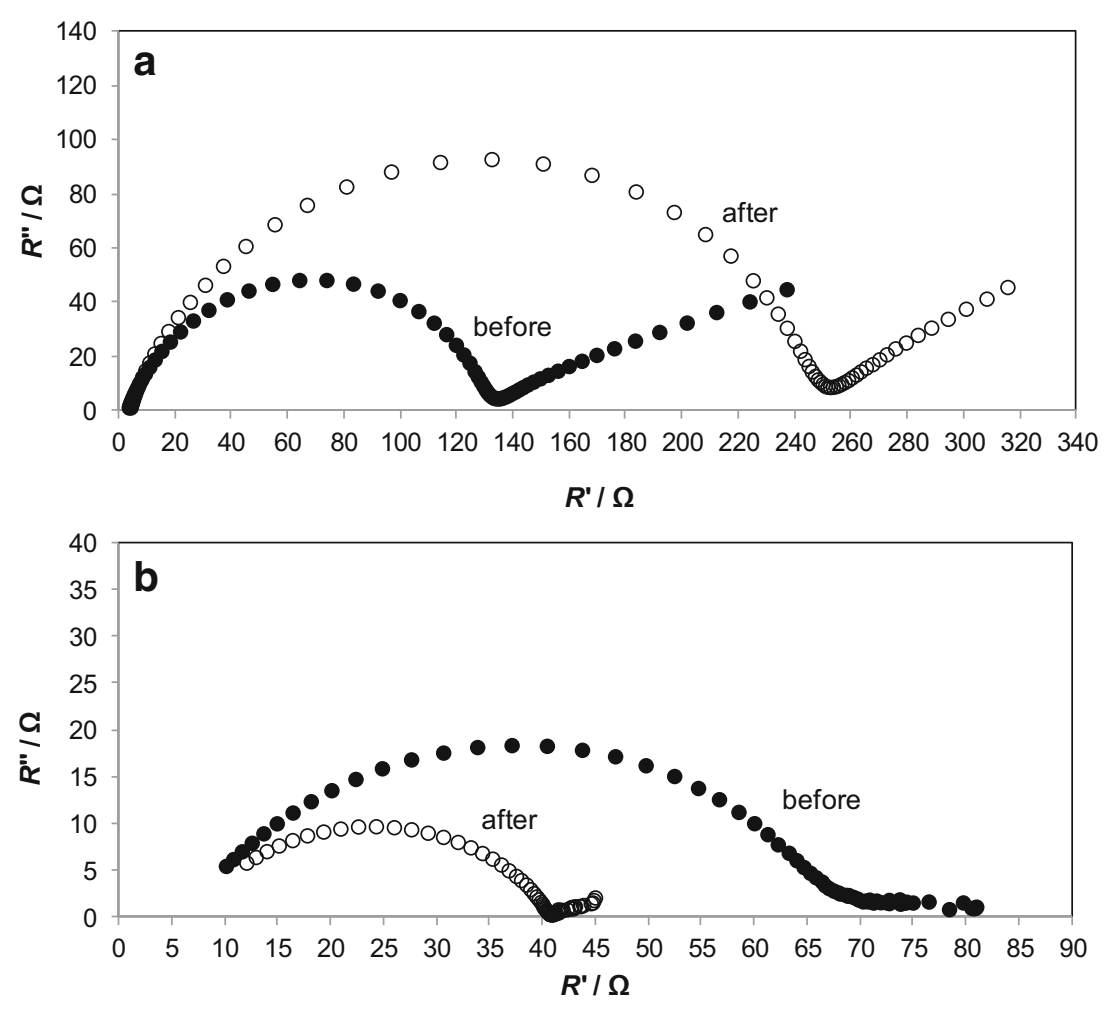

C

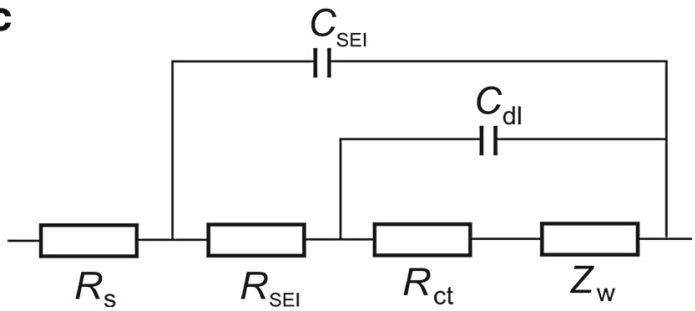

temperatures, the gaseous phase above the liquid electrolyte contains flammable component. The natural flammability of standard LIB carbonate-based electrolytes generates a fire risk, which may arise under abnormal abuse conditions. Fire tests suggest that the risk of thermal run-away may be much lower in the case of the PE.

\section{Conductivity}

Specific conductivity of the PE was investigated with the use of impedance spectroscopy with blocking $\mathrm{Au}|\mathrm{PE}+\mathrm{VC}| \mathrm{Au}$ golden electrodes (Fig. 6a) taken at temperatures between ca. 25 and $55^{\circ} \mathrm{C}$. Determined conductivities were between $2.5\left(25.2^{\circ} \mathrm{C}\right)$ and $3.5 \mathrm{mS} \mathrm{cm}{ }^{-1}\left(55.2^{\circ} \mathrm{C}\right)$. The slope of the
Fig. 8 Impedance spectroscopy of the $\mathrm{C}_{6} \mathrm{Li}|\mathrm{PE}+\mathrm{VC}| \mathrm{Li}$ cell after intercalation/deintercalation/ intercalation taken at different temperatures $\left(25-55^{\circ} \mathrm{C}\right)$. Frequency range $10^{5}-10^{-2} \mathrm{~Hz}$

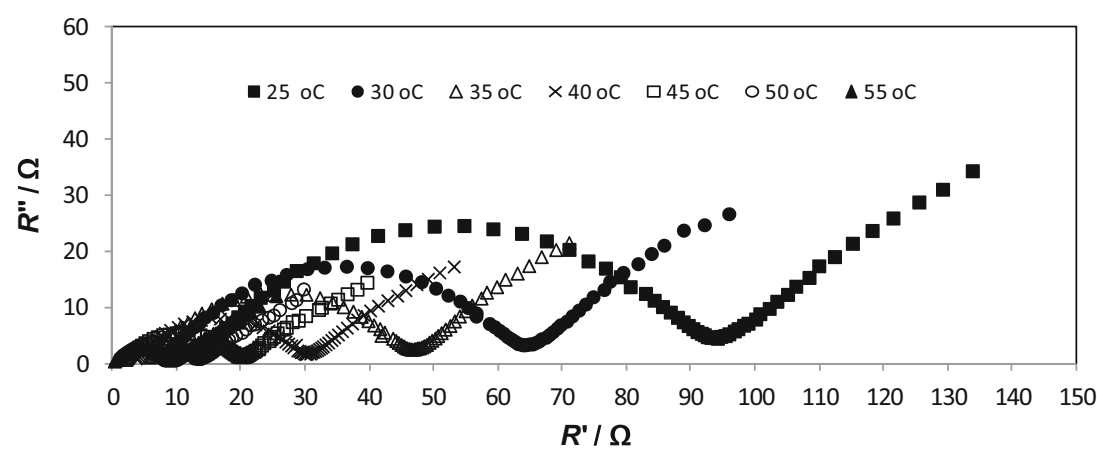


Arrhenius plot indicates activation energy of $9.0 \mathrm{~kJ} \mathrm{~mol}^{-1}$ for the conduction process ((Fig. 6b). These values may be compared with literature data on polymer and gel-type polymer electrolytes. The most popular host polymer is poly(ethylene oxide). Without addition of any plasticizer, solvent-free polymer electrolytes, including those based on PEO, show unacceptably low conductivity typically of the order of $10^{-8} \mathrm{mS} \mathrm{cm}^{-1}$ at room temperature [42]. Therefore, gel-type systems with a liquid component as a plasticizer were investigated, including non-volatile ionic liquids. Such a plasticizer (IL up to $40 \mathrm{wt} . \%$ ) increases conductivity by ca. 7 orders of magnitude to ca. $0.1 \mathrm{mS} \mathrm{cm}^{-1}[18-20,43,44]$. Another frequently studied host polymer was $\mathrm{PVdF}$ or its co-polymer with HFP: PVdF-co-HFP. In this case, the conductivity of the system polymer-IL- $\mathrm{Li}^{+}$salt was amounted to ca. $1-4 \mathrm{mS} \mathrm{cm}^{-1}[26,28$, 31]. Activation energy is usually reported to be ca. 5$25 \mathrm{~kJ} \mathrm{~mol}^{-1}[31,45,46]$. However, some polymer electrolytes show not the Arrhenius, but rather VTF type of behaviour [46].

\section{$\mathrm{Li} / \mathrm{Li}^{+}$charge transfer kinetics}

Figure 7a shows impedance spectra of the Li/PE/Li system before and after galvanostatic charging/discharging. It may be seen that charging/discharging processes resulted in increased impedance, probably due to the formation of a passivation layer. However, if the surface of the polymer electrolyte was covered with liquid VC (ca. $5 \mathrm{wt} \%$ versus mass of $\mathrm{PE}$ ), the impedance of the $\mathrm{Li} / \mathrm{PE}+\mathrm{VC} / \mathrm{Li}$ system taken before galvanostatic cycling (Fig. 7b) was lower in comparison to that shown in Fig. 7a. Moreover, galvanostatic cycling led to an almost twofold reduction of total impedance. This was due to the formation of SEI induced by the VC additive, which was converted into a conducting protective layer. In flammability tests, the $\mathrm{PE}$ with the $\mathrm{VC}$ after galvanostatic cycling showed similarity to that without the additive. This suggests that liquid $\mathrm{VC}$ was converted into a nonflammable solid phase (SEI) during cycling. Moreover, the interfacial resistance is improved by liquids contained by the gel-type PE. Deconvolution of impedance spectra shown in Fig. $7 \mathrm{~b}$ was performed according to an equivalent circuit shown in Fig. 7c. Estimated SEI and charge transfer resistances ( $R_{\mathrm{SEI}}$ and $R_{\mathrm{ct}}$, respectively) before cycling amounted to $R_{\mathrm{SEI}} \approx 30 \Omega$ and $R_{\mathrm{ct}} \approx 30 \Omega$. Galvanostatic cycling resulted in a decrease of these values to ca. $15 \Omega$. The charge transfer process takes place between a solid SEI layer and a solid $\mathrm{Li}$ electrode - in this case, the formation of the new layer also led to the reduction of resistance.

\section{$\mathrm{C}_{6} \mathrm{Li}_{/} / \mathrm{Li}^{+}$charge transfer kinetics}

Figure 8 shows impedance spectra of the graphite electrode after its intercalation with lithium, taken at different temperatures $\left(25-55^{\circ} \mathrm{C}\right)$. Spectra were deconvoluted using the same equivalent circuit as in the case of the metallic lithium anode.

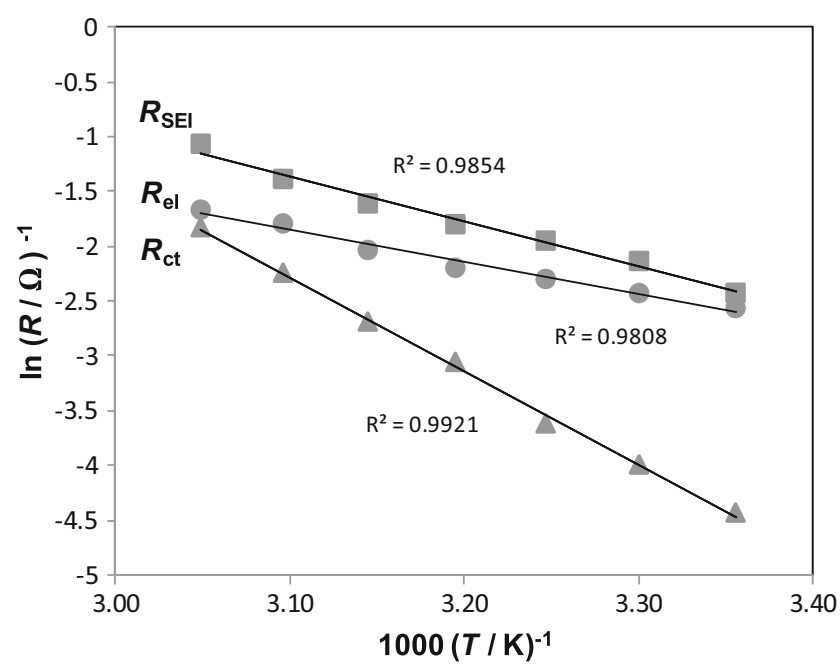

Fig. 9 Arrhenius plot for the $\mathrm{C}_{6} \mathrm{Li}|\mathrm{PE}+\mathrm{VC}| \mathrm{Li}$ cell after intercalation/ deintercalation/intercalation taken at different temperatures $\left(25-55^{\circ} \mathrm{C}\right)$

Charge transfer resistance of the $\mathrm{C}_{6} \mathrm{Li} \rightarrow \mathrm{Li}^{+}+\mathrm{e}^{-}$was estimated to be ca. $48 \Omega$ at $25^{\circ} \mathrm{C}$, somewhat higher, in comparison to the $\mathrm{Li} \rightarrow \mathrm{Li}^{+}+\mathrm{e}^{-}$process $(15 \Omega)$. A graphite anode may be used in practical systems, and hence, the activation energy was determined from Arrhenius plots (Fig. 9). The $\ln \left(R_{\mathrm{ct}}\right)=\mathrm{f}\left(\mathrm{T}^{-1}\right)$ curve was linear with a good correlation coefficient (expressed as $r 2$ ) of 0.992 . The determined activation energy of the charge transfer process was ca. $71 \mathrm{~kJ} \mathrm{~mol}^{-1}$. This value is comparable to that determined for the $\mathrm{C}_{6} \mathrm{Li}$ anode working together with a liquid $\mathrm{LiPF}_{6}$ solution in propylene carbonate $\left(71.1 \mathrm{~kJ} \mathrm{~mol}^{-1}\right)$ [47]. Compatibility of the PE with the graphite electrode was also verified using galvanostatic charging/discharging. Voltage-capacity plots of the $\mathrm{C}_{6} \mathrm{Li}|\mathrm{PE}+\mathrm{VC}| \mathrm{Li}$ cell using a polymer electrolyte with $5.5 \mathrm{wt} \% \mathrm{VC}$ at different current densities $(20,50$, and $100 \mathrm{~mA} \mathrm{~g}^{-1}$ ) are shown in Fig. 10. After the 30th cycle,

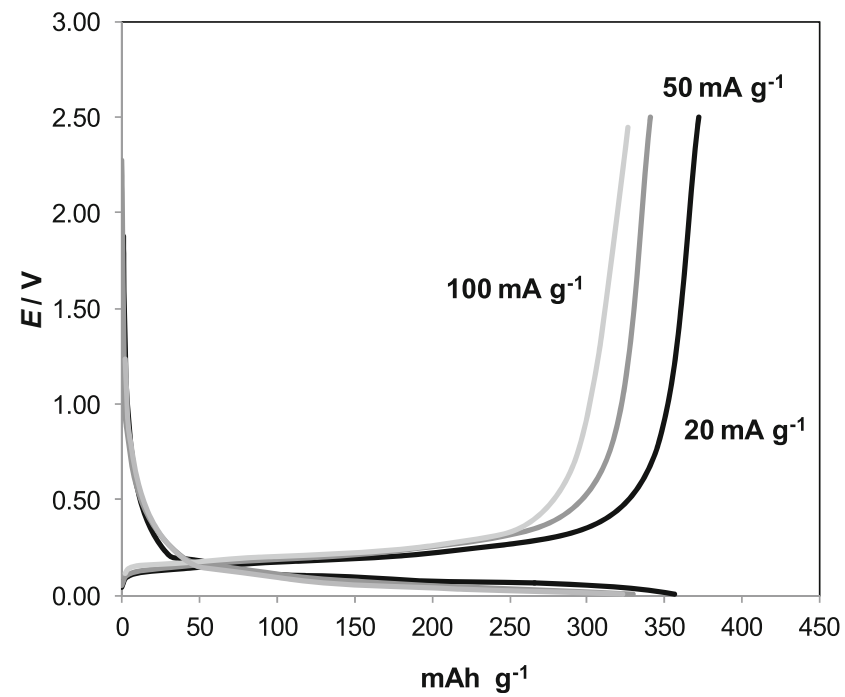

Fig. 10 Galvanostatic charge/discharge profiles of the $\mathrm{C}_{6} \mathrm{Li}|\mathrm{PE}+\mathrm{VC}| \mathrm{Li}$ cell at different rates $\left(20,50\right.$ and $\left.100 \mathrm{~mA} \mathrm{~g}^{-1}\right)$ 
capacity stabilized at ca. $350 \mathrm{mAh} \mathrm{g}^{-1}$. At higher rates, it was somewhat lower (330 and $310 \mathrm{mAh} \mathrm{g}^{-1}$ for 50 and $100 \mathrm{~mA} \mathrm{~g}^{-1}$, respectively).

\section{Conclusions}

A quaternary PAN-EMImBF 4 -TMS-LIPF 6 polymer electrolyte showing good mechanical properties may be prepared by the simple casting technique. SEM images revealed a structure consisting of a polymer network (PAN) and space probably occupied by the liquid phase $\left(\mathrm{LiPF}_{6}+\mathrm{EMImBF}_{4}+\right.$ TMS). The polymer electrolyte in contact with an outer flame source did not ignite; it rather undergoes softening - decomposition not resulting in the formation of flammable products. Specific conductivities were between $2.5\left(25.2{ }^{\circ} \mathrm{C}\right)$ and $3.5 \mathrm{mS} \mathrm{cm}{ }^{-1}\left(55.2{ }^{\circ} \mathrm{C}\right)$ with the activation energy of $9.0 \mathrm{~kJ} \mathrm{~mol}^{-1}$. Charge transfer resistance for the $\mathrm{C}_{6} \mathrm{Li} \rightarrow$ $\mathrm{Li}^{+}+\mathrm{e}^{-}$and $\mathrm{Li} \rightarrow \mathrm{Li}^{+}+\mathrm{e}^{-}$anode processes were ca. 48 and $15 \Omega$, respectively. Galvanostatic charging/discharging after the 30th cycle showed the graphite anode capacity at ca. $350 \mathrm{mAh} \mathrm{g}^{-1}$. The compatibility of the polymer electrolyte with the graphite anode suggests that the PE may be practically used in Li-ion batteries.

Acknowledgements Support of grant NCN UMO/2013/09/B/ST4/ 00107 is gratefully acknowledged.

Open Access This article is distributed under the terms of the Creative Commons Attribution 4.0 International License (http:// creativecommons.org/licenses/by/4.0/), which permits unrestricted use, distribution, and reproduction in any medium, provided you give appropriate credit to the original author(s) and the source, provide a link to the Creative Commons license, and indicate if changes were made.

\section{References}

1. Wakihara M, Yamamoto O (1998) Lithium ion batteries. Wiley$\mathrm{VCH}$, Tokyo

2. Scrosati B, Garche J (2010) J Power Sources 195:2419-2430

3. Aurbach D (2002) In: van Schalkwijk WA, Scrosati B (eds) Advances in lithium-ion batteries. Kluwer, New York

4. Galinski M, Lewandowski A, Stepniak I (2006) Electrochim Acta 51:5567-5580

5. Webber A, Blomgren GE (2002) In: van Schalkwijk WA, Scrosati B (eds) Advances in lithium-ion batteries. Kluwer, New York

6. Lewandowski A, Świderska-Mocek A (2009) J Power Sources 194:601-609

7. Guerfi A, Dontigny M, Charest P, Petitclerc M, Lagace M, Vijh A, Zaghib K (2010) J Power Sources 195:845-852

8. Fergus JW (2010) J Power Sources 195:4554-4569

9. Stephan AM (2006) European Polymer J 42:21-42

10. Ahmad S (2009) Ionics 15:309-321

11. Vincent CA, Scrosati B (1997) Modern batteries. Arnold, London

12. Li G, Li Z, Zhang P, Zhang H, Wu Y (2008) Pure Appl Chem 11: 2553-2563
13. Golodnitsky D, Strauss E, Peled E, Greenbaumd S (2015) J Electrochem Soc 162:A2551-A2566

14. Osada I, de Vries H, Scrosati B, Passerini S (2016) Angew Chem Int Ed 55:500-513

15. Shin JH, Henderson WA, Appetecchi GB, Alessandrini F, Passerini S (2005) Electrochim Acta 50:3859-3865

16. Shin JH, Henderson WA, Scaccia S, Prosini PP, Passerini S (2006) J Power Sources 156:560-566

17. Choi JW, Cheruvally G, Kim YH, Kim JK, Manuel J, Raghavan P, Ahn JH, Kim KW, Ahn HJ, Choi DS, Song CE (2007) Solid State Ionics 178:1235-1241

18. Kim GT, Appetecchi GB, Alessandrini F, Passerini S (2007) J Power Sources 171:861-869

19. Fisher AS, Khalid MB, Widstrom M, Kofinas P (2011) J Power Sources 196:9767-9773

20. An Y, Cheng X, Zuo P, Liao L, Yin G (2012) J Solid State Electrochem 16:383-389

21. Kim GT, Jeong SS, Xue MZ, Balducci A, Winter M, Passerini S, Alessandrini F, Appetecchi GB (2012) J Power Sources 199:239246

22. Joost M, Kim GT, Winter M, Passerini S (2013) Electrochim Acta 113:181-185

23. de Vries H, Jeong S, Passerini S (2015) RSC Adv 5:13598-13606

24. Kido R, Ueno K, Iwata K, Kitazawa Y, Imaizumi S, Mandai T, Dokko K, Watanabe M (2015) Electrochim Acta 175:5-12

25. Bansal D, Cassel F, Croce F, Hendrickson M, Plichta E, Salomon M (2005) J Phys Chem B 109:4492-4496

26. Cheruvally G, Kim JK, Choi W, Ahn JH, Shin YJ, Manuel J, Raghavan P, Kim KW, Ahn HJ, Choi DS, Song CE (2007) J Power Sources 172:863-869

27. Sirisopanaporn C, Fernicola A, Scrosati B (2009) J Power Sources 186:490-495

28. Li ZH, Xia QL, Liu LL, Lei GT, Xiao QZ, Gao DS, Zhou XD (2010) Electrochim Acta 56:804-809

29. Navarra MA, Manzi J, Lombardo L, Panero S, Scrosati B (2011) Chem Sus Chem 4:125-130

30. Liu LL, Li ZH, Xia QL, Xiao QZ, Lei GT, Zhou XD (2012) Ionics 18:275-281

31. Lewandowski A, Swiderska-Mocek A, Waliszewski L (2013) Electrochim Acta 92:404-411

32. Swiderska-Mocek A, Naparstek D (2014) Solid State Ionics 267: 32-37

33. Swiderska-Mocek A (2014) Electrochim Acta 139:337-344

34. Yoon HK, Chung WS, Jo NJ (2004) Electrochim Acta 50:289-293

35. Forsyth M, MacFarlane DR, Hill AJ (2000) Electrochim Acta 45: 1243-1247

36. Voigt N, van Wîllen L (2012) Solid State Ionics 208:8-16

37. Watanabe M, Mizumura T (1996) Solid State Ionics 86-8:353-356

38. Yuan J, Mecerreyes D, Antonietti M (2013) Prog Polym Sci 38: 1009-1036

39. Green O, Grubjesic S, Lee S, Firestone MA (2009) Polym Rev 49: 339-360

40. Pont AL, Marcilla R, De Meatza I, Grande H, Mecerreyes D (2009) J Power Sources 188:558-563

41. Yand H, Zhuang GV, Ross PN Jr (2006) J Power Sources 161:573-579

42. Gray FM (1991) Solid polymer electrolytes. VCH Publishers, New York

43. Kim YH, Cheruvally G, Choi JW, Ahn JH, Kim KW, Ahn HJ, Choi DS, Song CE (2007) Macromol Symp 249-250:183-189

44. Polu AR, Rhee HW (2017) Int J Hydrog Energy. doi:10.1016/j. ijhydene.2016.04.160

45. Zhai W, Zhu H, Wang L, Liu X, Yang H (2014) Electrochim Acta 133:623-630

46. Yang P, Liu L, Li L, Hou J, Xu Y, Ren X, An M, Li N (2014) Electrochim Acta 115:454-460

47. Xu K (2007) J Electrochem Soc 154:A162-A167 